\title{
Myofascial Pain Syndrome, myofascial trigger points and trigger points in veterinary medicine: a review
}

\author{
Revisão: Síndrome Dolorosa Miofascial, pontos gatilhos miofascial e \\ pontos gatilhos na medicina veterinária
}

\author{
Nadia Yuri Shimosaka Sato ${ }^{1}$ (D); Bárbara Buff Blumer Bastos² (D); Marco Aurélio Amador Pereira ${ }^{1}$ (D); \\ Karina D’Angelo Campos ${ }^{1}$ (D); Aline Magalhães Ambrósio ${ }^{1}$ (D); Maira Rezende Formenton ${ }^{1}$ (D); \\ Denise Tabacchi Fantoni ${ }^{1}$

\begin{abstract}
${ }^{1}$ Universidade de São Paulo, Faculdade de Medicina Veterinária e Zootecnia, Departamento de Cirurgia, São Paulo - SP, Brazil
\end{abstract} \\ ${ }^{2}$ Hospital Veterinário São Sebastião, São Sebastião - SP, Brazil
}

\begin{abstract}
Myofascial Pain Syndrome (MPS) a is a painful condition related to myofascial trigger points (TP) in skeletal muscle. The aim of this study was to perform a literature review on the etiology, pathophysiology, diagnosis and treatment of MPS in veterinary medicine. The research sites used for this purpose were: Scientific Electronic Library, PubMed and Medline. The inclusion criteria for the papers were: must be written in English; published between 1990 and 2018; include the following keywords: myofascial pain syndrome veterinary/dog/canine/cat/feline/horse/equine, trigger points veterinary/dog/canine/cat/feline/horse/equine. Through the review, it was observed that veterinary clinical studies are scarce, and the articles found lack information such as MPS description, incidence and specific treatment techniques in dogs and horses, and no studies in cats were found.
\end{abstract}

Keywords: Myofascial Pain Syndrome. Trigger points. Horses. Dogs.

\section{RESUMO}

Síndrome Dolorosa Miofascial (SDM) é uma condição dolorosa relacionada aos pontos gatilhos miofasciais (PG) no músculo esquelético. Este trabalho tem como objetivo realizar uma revisão bibliográfica sobre a etiologia, fisiopatogenia, diagnóstico e tratamento na medicina veterinária. Foram utilizados sites de pesquisas Scientific Electronic Library, Pubmed e Medline. Os critérios de inclusão estabelecidos foram: ser escrito em inglês; no período de 1990 a 2018; ter as palavras chaves para busca: myofascial pain syndrome veterinary/dog/canine/cat/feline/horse/equine, trigger points veterinary/dog/canine/cat/feline/horse/equine. Após a revisão observa-se que faltam estudos clínicos em medicina veterinária, sendo que os artigos encontrados se limitam à descrição, incidência e técnicas pontuais em cães e equinos, não sendo encontradas referencias em felinos.

Palavras-chave: Síndrome Miofascial Dolorosa. Pontos gatilhos. Equinos. Cães.

Correspondence to:

Nadia Yuri Shimosaka Sato

Universidade de São Paulo, Faculdade de Medicina Veterinária

e Zootecnia, Departamento de Cirurgia

Av. Prof. Dr. Orlando Marques de Paiva, 87, Butantã

CEP: 05508-900, São Paulo - SP, Brazil

e-mail: nadiayuriss@usp.br

Received: November 26, 2019

Approved: February 22, 2020
How to cite: Sato NYS, Bastos BBB, Pereira MAA, Campos KD, Ambrósio AM, Formenton MR, Fantoni DT. Myofascial Pain Syndrome, myofascial trigger points and trigger points in veterinary medicine: a review. Braz J Vet Res Anim Sci. 2020;57(2):e164351. https://doi.org/10.11606/ issn.1678-4456.bjvras.2019.164351 


\section{Introduction}

Myofascial Pain Syndrome (MPS) is described in medicine as a painful condition related to the presence of myofascial trigger points (TP) in the skeletal muscular system. Its presentations may be isolated, associated with concomitant chronic diseases, active or latent (Borg-Stein \& Iaccarino, 2014; Fernández-de-Las-Peñas \& Nijs, 2019). In humans, it affects muscles, connective tissue and fascia, especially in the cervical, scapular and lumbar regions (Teixeira et al., 2001; Yeng et al., 2001).

TP or myofascial trigger point is defined as a focus of muscle hyperirritability that generates a painful stimulus to the skeletal muscle system. TPs might be palpable and are associated with strained muscle bands or "knots". If manual pressure is applied to the TPs, the patient feels local and referred pain (Borg-Stein \& Iaccarino, 2014; Fernández-de-Las-Peñas \& Nijs, 2019; Gerwin, 2014; Simons, 2002; Teixeira et al., 2001).

In humans, the prevalence of MPS ranges from $21 \%$ to $30 \%$ in the general population or even $85 \%$ to $90 \%$ in people with chronic pain (Borg-Stein \& Iaccarino, 2014). MPS is described as a strong limiting condition by people who have it, since it is related to work absence and increased time of low back pain treatment. Furthermore, in oncology patients, it may increase morbidity and mortality due to its intrinsically associated low blood levels of magnesium and 25-hydroxyvitamin D (Landis \& Koch, 1977; Teixeira et al., 2001; Yeng et al., 2001).

The first study describing TP was published in 1991 and was performed in dogs by Janssens (1991). Hong \& Simons (1998) later used rabbits as an experimental model to study the pathophysiology of TP and demonstrated that TP, also referred pain and muscle contracture, are linked to integrative spinal cord mechanisms and excessive acetylcholine release.

The growing interest of veterinary professionals in emerging disciplines such as physical rehabilitation and sports medicine, as well as the increasing incidence of chronic diseases that affect the locomotor system in horses and companion animals, knowledge about MPS and TP is of great importance (Simons \& Dommerholt, 2006; Wall, 2014). This study aims to present a literature review on the etiology, pathophysiology, diagnosis and treatment of Myofascial pain syndrome and myofascial trigger points in veterinary medicine, with an emphasis on dogs, cats and horses.

\section{Materials and Methods}

The literature review was performed in 3 steps: search for journals, eligibility evaluation and development of the discussion based on the selected articles. The search for journals was performed by a reviewer, within a three month period, by electronically searching the Scientific Electronic Library research sites (Scientific Electronic Library Online, 2019), PubMed (National Center for Biotechnology Information, 2019) and Medline (Centro Latino-Americano e do Caribe de Informação em Ciências da Saúde, 2019) for articles and scientific papers related to MPS in veterinary patients.

The inclusion criteria were: the articles must be written in English; published between 1990 and 2018; and include the following keywords: myofascial pain syndrome veterinary/dog/canine/cat/feline/horse/equine, trigger points veterinary/dog/canine/cat/feline/horse/equine. Sixty articles and references were selected, 30 of which in PubMed and the other 30 in Medline. Exclusion criteria were: theses references, book chapters and citations, abstracts or references of congress proceedings, studies in other species and outside the proposed period.

Eligibility evaluation was performed in two stages: quantitative and qualitative selection. In the quantitative selection, 45 articles had to be excluded as they were duplicated, and one was excluded since its publication date was not within the proposed period.

In the qualitative selection, two reviewers read the 15 articles and classified each one as: strong, weak or unrelated to the topic (including articles that were not available). Afterwards, Fleiss's Kappa agreement analysis was performed and it was found that 13 articles showed substantial relation to the study's topic (kappa $=0.761468$ ), according to Landis \& Koch (1977). The process of research and eligibility evaluation is illustrated in Figure 1. Technical files of the articles were prepared containing information on author, title, species, type of article, results and conclusion. The two reviewers then developed the discussion.

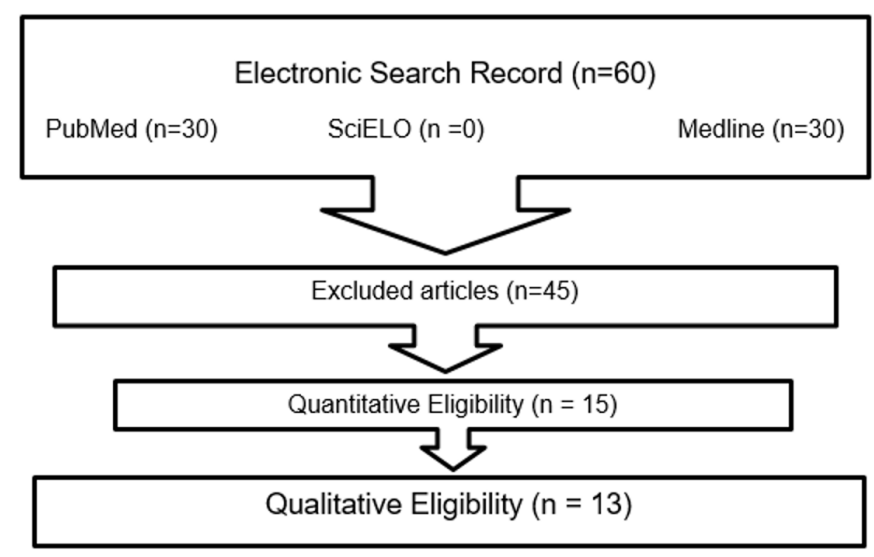

Figure 1 -Stages of article selection with Electronic Search, exclusion, quantitative and qualitative eligibility. Legend: (n): sample number. 


\section{Results}

Three observational clinical studies, two prospective clinical studies, three original articles, four bibliographic reviews and one case report were selected. One of them addressed horses, dogs and cats; two were about dogs and cats; three regarded dogs only; and six concerned horses. No articles specifically addressed cats.

Table 1 details of the technical file used to guide the discussion on Myofascial Pain Syndrome and Myofascial trigger point in horses, dogs and cats.

Table 1 - Technical file summarizing the major publications on Myofascial Syndrome and Trigger Points in Horses, Dogs and Cats

\begin{tabular}{|c|c|c|c|c|c|}
\hline Author & Title & $\begin{array}{l}\text { Article } \\
\text { Modality }\end{array}$ & Species & Materials and Methods & Results and Conclusion \\
\hline $\begin{array}{l}\text { Brockman } \\
(2017)\end{array}$ & $\begin{array}{l}\text { A case study } \\
\text { utilizing } \\
\text { myofascial release, } \\
\text { acupressure } \\
\text { and trigger } \\
\text { point therapy to } \\
\text { treat bilateral } \\
\text { "stringhalt" in } \\
\text { a } 12 \text { year old } \\
\text { Akhal-teke horse }\end{array}$ & Case Report & Horse & $\begin{array}{l}\text { A 12-year-old Akhal-teke horse } \\
\text { with high flexion of the right pelvic } \\
\text { limb underwent treatment with } \\
\text { myofascial release of cervical, sacrum } \\
\text { and ilium muscles, bladder meridian } \\
\text { acupressure (including spine, spine, } \\
\text { lumbar hamstrings) and TP release } \\
\text { from the iliac region. Frequently twice } \\
\text { a week for } 1 \text { hour and a half each } \\
\text { session }\end{array}$ & $\begin{array}{l}\text { Massage therapy with myofascial } \\
\text { release, acupressure and TP release } \\
\text { proved to be an alternative for } \\
\text { horses with high limb flexion. } \\
\text { In this case report there was a } \\
\text { decrease in the frequency and } \\
\text { intensity of muscle spasms and an } \\
\text { improvement of } 50 \text { to } 85 \% \text { in the } \\
\text { incidence of high flexion of the } \\
\text { affected pelvic limb. }\end{array}$ \\
\hline $\begin{array}{l}\text { Downing } \\
(2011)\end{array}$ & $\begin{array}{l}\text { The role of physical } \\
\text { medicine and } \\
\text { rehabilitation } \\
\text { for patients in } \\
\text { palliative and } \\
\text { hospice care }\end{array}$ & $\begin{array}{l}\text { Original } \\
\text { article }\end{array}$ & $\begin{array}{l}\text { Dog } \\
\text { Cat }\end{array}$ & $\begin{array}{l}\text { Review of the types of rehabilitation } \\
\text { and their benefits in palliative } \\
\text { care patients. Therapies such as } \\
\text { heat / cold therapies, massage } \\
\text { therapy, chiropractic, acupuncture and } \\
\text { myofascial TP release were addressed. }\end{array}$ & $\begin{array}{l}\text { Patients in palliative care are most } \\
\text { often carriers of chronic diseases } \\
\text { and different rehabilitation } \\
\text { modalities can bring pain relief, } \\
\text { reduce medication use and bring } \\
\text { comfort to terminally ill patients. }\end{array}$ \\
\hline Frank (1999) & $\begin{array}{l}\text { Myofascial trigger } \\
\text { point diagnostic } \\
\text { criteria in dog }\end{array}$ & $\begin{array}{l}\text { Prospective } \\
\text { clinical study }\end{array}$ & Dog & $\begin{array}{l}600 \text { dogs were evaluated according } \\
\text { to the evaluation and diagnosis } \\
\text { criteria of MPS used in humans } \\
\text { with assessment of restricted range } \\
\text { of motion, band palpation, local } \\
\text { sensitivity, jumping signal, contractile } \\
\text { response, muscle weakness or loss of } \\
\text { proprioception, pain recognition and } \\
\text { referred pain in sensitized areas. }\end{array}$ & $\begin{array}{l}\text { The evaluation and diagnosis } \\
\text { criteria of myofascial painful } \\
\text { syndrome used in humans have } \\
\text { proven to be effective in developing } \\
\text { a diagnostic and therapeutic } \\
\text { approach for this syndrome in dogs. }\end{array}$ \\
\hline Fry et al. (2014) & $\begin{array}{l}\text { Acupuncture } \\
\text { for analgesia } \\
\text { in veterinary } \\
\text { medicine. }\end{array}$ & Review article & $\begin{array}{l}\text { Horse } \\
\text { Dog } \\
\text { Cat }\end{array}$ & $\begin{array}{l}\text { Review of the indication and } \\
\text { mechanisms of action of acupuncture }\end{array}$ & $\begin{array}{l}\text { Many acupuncture points are near } \\
\text { or associated with regions with } \\
\text { musculoskeletal dysfunction, such } \\
\text { as TP. } \\
\text { Acupuncture should be part of the } \\
\text { multimodal approach for treating a } \\
\text { wide variety of painful conditions, } \\
\text { including TP release. }\end{array}$ \\
\hline $\begin{array}{l}\text { Formenton et al. } \\
\qquad(2017)\end{array}$ & $\begin{array}{l}\text { Small animal } \\
\text { massage therapy: } \\
\text { a brief review } \\
\text { and relevant } \\
\text { observations }\end{array}$ & Review article & $\begin{array}{l}\text { Dog } \\
\text { Cat }\end{array}$ & $\begin{array}{l}\text { This is a review of the main aspects } \\
\text { of massage therapy described in } \\
\text { human physiotherapy, extrapolating } \\
\text { such techniques to small patients } \\
\text { (dogs and cats). }\end{array}$ & $\begin{array}{l}\text { The benefits of massage therapy seen } \\
\text { in dogs and cats can be compared } \\
\text { to those seen in humans with pain } \\
\text { relief and applicability in orthopedic } \\
\text { rehabilitation, canine sports medicine, } \\
\text { intensive care and treatment of } \\
\text { nonspecific edema. It is a promising } \\
\text { therapy modality that needs studies } \\
\text { in domestic animals. }\end{array}$ \\
\hline $\begin{array}{l}\text { Bowen et al. } \\
\qquad(2017)\end{array}$ & $\begin{array}{l}\text { Investigation of } \\
\text { myofascial trigger } \\
\text { points in equine } \\
\text { pectoral muscles } \\
\text { and girth-aversion } \\
\text { behavior }\end{array}$ & $\begin{array}{l}\text { Cross- } \\
\text { sectional } \\
\text { study }\end{array}$ & Horse & $\begin{array}{l}\text { Thirty-eight horses with Girth- } \\
\text { Aversion Behaviors were selected for } \\
\text { physiotherapeutic investigation of } \\
\text { myofascial trigger points in equine } \\
\text { pectoral muscles and to correlate TP } \\
\text { pain score with behavioral changes. }\end{array}$ & $\begin{array}{l}\text { Incident of TP in the pectoral region is } \\
\text { described in the armpit region in the } \\
\text { laryngeal portion of the ascending } \\
\text { pectoral muscle, to the right of the } \\
\text { sternum and across the circumference } \\
\text { region and towards the edges of the } \\
\text { muscles. } \\
\text { And horses that presented severe } \\
\text { pain with the manipulation } \\
\text { of TPs showed more evident } \\
\text { Girth-Aversion Behaviors. }\end{array}$ \\
\hline
\end{tabular}


Table 1 - Continued...

\begin{tabular}{|c|c|c|c|c|c|}
\hline Author & Title & $\begin{array}{c}\text { Article } \\
\text { Modality }\end{array}$ & Species & Materials and Methods & Results and Conclusion \\
\hline Janssens (1991) & $\begin{array}{l}\text { Trigger points } \\
\text { in } 48 \text { dogs with } \\
\text { myofascial pain } \\
\text { syndromes }\end{array}$ & $\begin{array}{l}\text { Prospective } \\
\text { clinical study }\end{array}$ & Dog & $\begin{array}{l}\text { Forty-eight dogs were studied for } \\
\text { TP recognition and treated with dry } \\
\text { needling technique and anesthetic } \\
\text { infiltration. The dogs were divided } \\
\text { into } 2 \text { groups and the treatment was } \\
\text { performed weekly for } 8 \text { weeks. }\end{array}$ & $\begin{array}{l}\text { Seven points of TPs were identified: } \\
\text { brachial triceps, infraspinatus, } \\
\text { pectineus adductor, long fibular, } \\
\text { middle gluteus, iliopsoas and } \\
\text { quadriceps femoral muscles } \\
35 \text { to } 60 \% \text { of the animals showed } \\
\text { favorable response to the treatment } \\
\text { performed. }\end{array}$ \\
\hline $\begin{array}{l}\text { MacGregor \& } \\
\text { Von Schweinitz } \\
\text { (2006) }\end{array}$ & $\begin{array}{l}\text { Needle } \\
\text { electromyography } \\
\text { activity of } \\
\text { myofascial trigger } \\
\text { points and control } \\
\text { sites in equine } \\
\text { cleido-brachialis } \\
\text { muscle--an } \\
\text { observational } \\
\text { study. }\end{array}$ & $\begin{array}{l}\text { Prospective } \\
\text { clinical study }\end{array}$ & Horse & $\begin{array}{l}\text { Four horses with signs of TP in the } \\
\text { cleido-brachial muscle underwent } \\
\text { spontaneous electrical activity } \\
\text { evaluation of the muscle at the TP } \\
\text { point (acupuncture point L16) and } \\
\text { control point (acupuncture point } \\
\text { L17 or ST10). }\end{array}$ & $\begin{array}{l}\text { The study demonstrated } \\
\text { spontaneous electrical activity } \\
\text { (SEA) in the equine cleido-brachial } \\
\text { muscle, sites determined by } \\
\text { palpation to be active PT compared } \\
\text { to SEA at control sites. } \\
\text { There is incidence of TP in equine } \\
\text { cleido-brachial muscle }\end{array}$ \\
\hline $\begin{array}{l}\text { Pellegrini et al. } \\
\qquad(2020)\end{array}$ & $\begin{array}{l}\text { Equine } \\
\text { acupuncture } \\
\text { methods and } \\
\text { applications: A } \\
\text { review } \\
\text { D. }\end{array}$ & Review article & Horse & $\begin{array}{l}\text { Review that discusses the applications } \\
\text { of acupuncture and its eastern } \\
\text { medical philosophy in equine health, } \\
\text { as well as the main techniques used } \\
\text { to stimulate acupuncture points in } \\
\text { equine practice. }\end{array}$ & $\begin{array}{l}\text { The techniques used in acupuncture } \\
\text { are based on endogenous / } \\
\text { homeostatic mechanisms to lead } \\
\text { to 'self-healing'. Acupuncture can } \\
\text { be considered complementary and } \\
\text { integrative in a setting of equine } \\
\text { clinical practice. }\end{array}$ \\
\hline Ridgway (1999) & $\begin{array}{l}\text { Acupuncture as a } \\
\text { treatment modality } \\
\text { for back problems }\end{array}$ & $\begin{array}{l}\text { Original } \\
\text { article }\end{array}$ & Horse & $\begin{array}{l}\text { Discusses acupuncture techniques } \\
\text { and methods, including dry needling, } \\
\text { electro acupuncture, acupuncture } \\
\text { using hypodermic needles, and } \\
\text { injection of various solutions at } \\
\text { acupuncture sites in patients with } \\
\text { radiculopathy and MPS. }\end{array}$ & $\begin{array}{l}\text { Acupuncture treatment may have } \\
\text { benefits for horses with diffuse MPS, } \\
\text { but it is essential to combine other } \\
\text { therapies for the recovery of horses } \\
\text { with radiculopathies. }\end{array}$ \\
\hline Rogers (2012) & $\begin{array}{l}\text { Acupuncture for } \\
\text { Equine Paraspinal } \\
\text { Myofascial Pain }\end{array}$ & $\begin{array}{l}\text { Prospective } \\
\text { clinical study }\end{array}$ & Horse & $\begin{array}{l}\text { Study on the incidence and treatment } \\
\text { with acupuncture of TPs in purebred } \\
\text { horses in the neck paraspinal muscles, } \\
\text { thoracolumbar area, croup (sacroiliac, } \\
\text { gluteal and hip area) and triceps and } \\
\text { hamstring muscles with identification } \\
\text { of pressure-reactive zones with } \\
\text { assistance probe (ZRPS). }\end{array}$ & $\begin{array}{l}\text { Acupuncture treatment following } \\
\text { ZRPS standards presents } \\
\text { favorable response with improved } \\
\text { performance of animals in a short } \\
\text { time. In this study, a higher incidence } \\
\text { of right hip pain was observed, with } \\
\text { compensatory pain in the left neck } \\
\text { over the C5-C7 vertebrae. }\end{array}$ \\
\hline $\begin{array}{c}\text { Von Schweinitz } \\
\text { (1999) }\end{array}$ & $\begin{array}{l}\text { Thermographic } \\
\text { diagnostics in } \\
\text { equine back pain }\end{array}$ & $\begin{array}{l}\text { Original } \\
\text { article }\end{array}$ & Horse & $\begin{array}{l}\text { Description of the thermographic } \\
\text { diagnostic method in low back pain } \\
\text { horses. }\end{array}$ & $\begin{array}{l}\text { Thermography is a fast, safe, } \\
\text { noninvasive complementary } \\
\text { assessment method that can assist } \\
\text { in monitoring response to low back } \\
\text { pain treatment in horses. }\end{array}$ \\
\hline Wall (2014) & $\begin{array}{l}\text { Introduction to } \\
\text { myofascial trigger } \\
\text { points in dogs }\end{array}$ & Review article & Dog & $\begin{array}{l}\text { Review of etiology, clinical } \\
\text { manifestations, diagnosis and } \\
\text { treatment of TP in dogs. }\end{array}$ & $\begin{array}{l}\text { The presence of TP in dogs leads to } \\
\text { pain and locomotor dysfunction. } \\
\text { Thus, the development of } \\
\text { identification skills, as well as } \\
\text { familiarity with the most affected } \\
\text { regions of TP and finally the } \\
\text { knowledge of treatment techniques } \\
\text { are necessary for the effective } \\
\text { management of TP in dogs. }\end{array}$ \\
\hline
\end{tabular}

\section{Discussion}

\section{Dogs and cats}

Although the term MPS is not routinely used in companion animals medicine, the existence of TP in dogs has been known since the 1990s. TP have been described in the following muscle groups that are overloaded by the hip joint: flexor (including iliopsoas), adductor and extensor muscles (Wall, 2014), pectin, long fibular, middle gluteal and quadriceps femoris muscles (Janssens, 1991). There are also reports in muscles overloaded by the thoracic limbs: infraspinatus, deltoid and triceps brachii muscles (Janssens, 1991; Wall, 2014). 
The clinical manifestations of patients with MPS or TP may include sensory, motor or autonomic alterations. Its sensory characteristics are related to pain. Human patients report diffuse and deep pain that is hard to locate when the tense band (TB) is palpated. Dogs can show behavior changes such as limb withdrawal or vocalization when TP are manipulated (Wall, 2014).

Motor characteristics may be related to muscle atrophy, muscle weakness, decreased range of motion and local twitch responses (LTR). The presence of a TP in a muscle can inhibit the contractile strength of adjacent muscles, leading to muscle weakness. Muscle atrophy may be due to disuse of the limb. LTR is a spinal cord response, where contraction of a taunt band is observed after direct TP stimulation with manual palpation or introduction of a needle. The presence of LTR in dogs corroborates the existence of TP (Wall, 2014).

TP consist of muscle fibers with intensely contracted sarcomeres with increased diameter and are usually called "knots". However, the pathophysiology involving the formation of these "knots" is not yet well understood. However, in 2004 a hypothesis was raised and suggested that muscle injury leads to high intracellular calcium concentrations (outside of the sarcoplasmic reticulum) and excessive acetylcholine release due to a motor end-plate dysfunction, which results in the shortening of sarcomeres (Wall, 2014).

The factors described as having the greatest impact on TP and MPS formation and perpetuation are postural changes due to orthopedic problems, postoperative or post-traumatic complications, pain related to neuropathies and arthropathies, especially osteoarthritis, and most frequently it is associated with stress mechanisms due to chronic muscle overload (Fry et al., 2014). It is not known whether nutritional or metabolic factors may contribute to the formation of TP and MPS (Wall, 2014), however Formenton et al. (2017) suggests that cancer patients undergoing surgical treatment with extensive manipulation show myofascial adhesions, as described in humans.

Very often, MPS and TP are neglected and may cause behavior changes or clinical signs related to pain chronification processes. In these cases, peripheral or central sensitization mechanisms are activated, which result in decreased pain threshold and increased peripheral receptor response or in physicochemical changes in the central nervous system that increase neuron excitability, respectively (Wall, 2014).

The criteria for identification of TP are well established in humans, as described in Table 2. Thus, Frank (1999) applied these criteria to dogs with general lameness, without specifying the studied muscle groups and confirmed the presence of TP in dogs, showing the similarity between the diagnosis in both species.

The animal's reaction to TP manipulation varies according to the severity of the problem and the response of each patient, however some behavioral findings may lead to a definite conclusion that the animal is in discomfort, such as looking toward the palpated region, aggressiveness, physiological changes such as pupil dilation and/or if the owner reports falling down or tiredness after exercise (Frank, 1999).

Referred pain in animals is controversial, as most authors point out that animals cannot describe the intensity and the delimitation of the affected area, leading to a compromised assessment (MacGregor \& Von Schweinitz, 2006). On the other hand, Frank believes that animals may exhibit behavior changes such as self-mutilation, licking the affected area, rubbing their ears or shaking their heads as reported by the owners, or may show limb withdrawal after applying non-painful tactile stimuli, in a similar way to the assessment of tactile allodynia in the region adjacent or caudal to the TP performed by the veterinarian during the physical examination (Frank, 1999).

Some TP palpation techniques can be employed by physiotherapy professionals, such as flat palpation, in which an evaluation is performed with finger pressure along the muscle fiber in a right angle supported by a firm

\section{Table 2 - Modified from Simons (2002)}

\section{Clinical history \\ - Complaint of pain or observation of behavioral changes related to acute, chronic symptoms or repetitive muscle overload of some region.}

- Pain of mild to moderate intensity related to some movement, positioning or even severe intensity when the pain is persistent.

Diagnostic Findings

- Restricted range of motion with painful component

- Presence of palpable taut band

- Sensitivity to palpation at the site of muscle straining bands

- Reproduction of pain in the patient

- Referred pain

- Weakness

- Autonomic signs (skin heat or erythema, tearing, piloerection) Confirmatory Findings

- Local contraction induced by palpation or needling when manipulated TP observed on physical or ultrasound examination.

- Referred pain

- Visualization of "terminal plate noise" when electromyography TP needling 
adjacent structure, such as the bone used for palpation of the infraspinatus, supraspinatus or psoas major muscles. Another technique is pincer palpation, in which the evaluation of part of a muscle is performed by holding it like a pincer and sliding the muscle fibers with the finger tips. This technique is used to evaluate the triceps, sartorius and tensor fascia lata muscles, and professional qualification is necessary to familiarization with the TP recognition (Wall, 2014). Studies relating thermography, TP or MPS algometry in dogs are scarce.

The treatment of MPS and TP can be divided into noninvasive and invasive techniques. Noninvasive treatments consist of laser therapy, electrotherapy and massage therapy. According to Wall, low-level laser therapy is widely used in humans to treat MPS and may also be applicable to dogs. Electrotherapy is employed in acute and chronic pain management in dogs, and even though studies on this topic are scarce, it is believed that it may also benefit MPS and TP patients (Wall, 2014).

Massage therapy is a recent modality with little scientific evidence in dogs and cats, however Formenton et al. (2017) reported that manual techniques such as Effleurage, kneading, petrissage, rubbing, tapping, vibration and shaking can be applied to dogs and cats and produce beneficial effects such as pain relief. This modality of therapy is applicable to orthopedic rehabilitation, canine sports medicine, intensive care and treatment of nonspecific edema. Furthermore, in cancer patients, massage therapy can produce pain modulation and consequently increase their quality of life.

The invasive techniques consist of dry needling or infiltration with local anesthetics or saline solution. Regarding the dry needling technique, acupuncture needles are often employed and once the tense band is recognized, the TP needling is performed until one or more LTR are observed. The depth of needle insertion ranges from 0.5 to $5 \mathrm{~cm}$ according to the patient's TP and body condition score, and the recommended duration of the needling is 5 minutes (Janssens, 1991).

As for the drug infiltration technique, hypodermic needles and $1 \%$ lidocaine are used. The volume ranges from 0.25 to $2 \mathrm{ml}$ per TP. The recommended interval between applications in chronic cases is once a week, however it may be performed after smaller intervals in cases of acute low back pain (Janssens, 1991; Wall, 2014). Comparing the techniques, Janssens observed that the dry needling technique brought discomfort to dogs, especially due to its duration, and drug infiltration was better tolerated (Janssens, 1991).
A clinical study performed weekly dry needling or drug infiltrations in dogs diagnosed with MPS for 8 weeks and it was observed that $60 \%$ of them showed improvement. Moreover, it was found that the dogs responded in two different ways; the group of dogs that had isolated TP located in the triceps, infra-spinal, quadriceps or adductor and pectineus muscles showed a good response to treatment. However, the other group that showed symmetrical TP in the pelvic limbs or multiple TP presented a poor response to treatment, and these dogs were even compared to human patients with fibromyalgia (Janssens, 1991).

That study also observed that four points frequently identified as TP coincide with some acupoints used in Chinese medicine: the peroneus longus bladder-34, the adductor-pectineus point liver-10 or 11 , the gluteus medius point bladder- 29 and the infraspinatus point small intestine-10 infraspinatus point. It is unclear what is the correlation between TP and acupoints and even if patients undergoing dry needling due to TP may benefit from acupuncture analgesic mechanisms complementarily (Downing, 2011; Fry et al., 2014; Janssens, 1991).

\section{Horses}

In horses, MPS and TP are related to behavioral changes linked to riding aversion or poor performance (Bowen et al., 2017; Rogers, 2012). TP in horses have been described in the cervical and pectoral muscles as well as in the cleido-brachial muscles (MacGregor \& Von Schweinitz, 2006), axillary region in the laryngeal portion of the ascending pectoral muscle (Bowen et al., 2017), triceps, ischio-tibial muscles, neck paraspinal muscles, muscles affecting the gluteus and hip areas (Rogers, 2012), or they even affect the muscles adjacent to the thoracolumbar and sacroiliac spine (Brockman, 2017). Figure 2 illustrates the mapping of TP observed in the pectoral region of horses.

The etiology involves mechanical and nervous stresses, such as compression, poor posture, chronic or acute muscular overload and metabolic diseases, due to reduced local circulation, low oxygenation and $\mathrm{pH}$ acidification and consequent onset of inflammation and pain (Bowen et al., 2017; Landis \& Koch, 1977). It may be related to some diseases such as chronic low back pain in horses, in which the incidence of TP and neurological changes may perpetuate local pain, leading to peripheral and central sensitization processes (Ridgway, 1999).

Based on the diagnostic criteria for MPS in humans, 3 of 5 criteria were observed in equine cleido-brachial muscles: the presence of palpable taut bands (TB), painful tense bands upon manual palpation and the presence of 


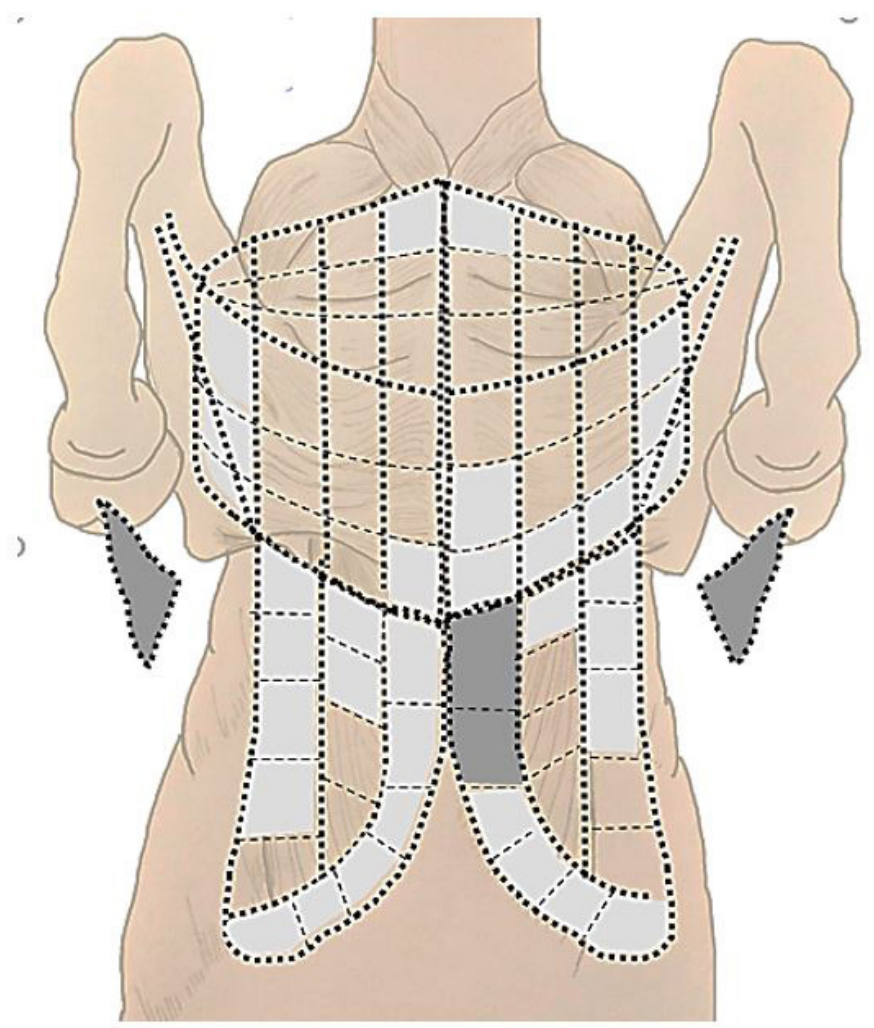

Figure 2 -Modified from Bowen et al. (2017). Map of the transverse and ascending pectoral muscles seen ventrally; frequency and severity of TPs in 38 horses. Degree of severity correlated with shade of transparent: light $0-1$, light gray: moderate $>1-2$, and dark gray: severe $>2-3$.

LTR after palpation and application of dry needling in the studied TP. Furthermore, it was shown that there is spontaneous electrical activity in the muscle with TP, corroborating with the Integrated Trigger Point Hypothesis (2004) (Gerwin et al., 2004; MacGregor \& Von Schweinitz, 2006; Wall, 2014).

The electrical activities observed in the study by MacGregor \& Von Schweinitz (2006) are similar to those observed in rabbits and humans with MPD. Given the release of acetylcholine, there is depolarization of muscle membranes, thus resulting in the propagation of negative and positive potentials. Sarcomere contracture may occur because depolarization occurs continuously and consequently the formation of tensioned bands is perpetuated (MacGregor \& Von Schweinitz, 2006).

The diagnosis of TP in a thoroughbred horse was described after identifying areas called "probe-assisted pressure reactive zones" (ZRPS). Rogers (2012) describes as "probe" a rigid consistency and smooth surface material that aids in the identification of TP after promoting a slight homogeneous pressure on the patient's skin. ZRPS mapping extended to all muscles of the dorsal cervical region and to the muscles adjacent to the thoracic, thoraco-lumbar and lumbar spine. ZRPS regions with muscle spasms were considered, or regions where, after manipulation, the animal responded with pain-related behavioral changes, such as grunts, looking at the area, kicking or moving away from the evaluator, extending from 10 to $30 \mathrm{~cm}$ in length. according to its location (MacGregor \& Von Schweinitz, 2006; Rogers, 2012).

Behavior changes are common in patients with TP. Horses with Girth-Aversion Behavior and TP showed behaviors such as turning their heads towards the waist area, biting, beating, kicking, flattening their ears, wagging their tail (Bowen et al., 2017), as well as horses evaluated for ZRPS identification as described previously (Rogers, 2012). They may also be related to shoulder muscle spasms or thoracic limb ataxia when they have TP in the scapular region, for example (Pellegrini et al., 2020).

Other instruments, such as algometer or thermography, may help with the diagnosis of MPS and TP. Although thermography did not show a strong correlation with focal $\mathrm{TP}$, it was useful to identify areas of TP with changes in acupuncture-treated vasomotor tone (Von Schweinitz, 1999).

For the treatment of MPD in horses, the authors emphasize the importance of correctly identifying TP in order to implement preventive strategies that aim to improve sport horses' comfort, optimize performance and reduce riding aversion behavior (Bowen et al., 2017). As described in dogs, the treatment for MPS and TP includes noninvasive and invasive techniques that can be used alone or in combination (Ridgway, 1999).

Bowen et al. (2017) observed that as pectoral region TP were released with stretching, horses improved Girth-Aversion behaviors. Brockman (2017) described a favorable response from the combination of massage and acupuncture in a horse with high flexion of the pelvic limbs, showing a decrease in the frequency and intensity of muscle spasms and a 50 to $85 \%$ improvement in the incidence of high limb flexion that affected the pelvic limb. Laser therapy has anti-inflammatory and analgesic properties and it is a noninvasive, painless technique that may be associated with acupuncture (Pellegrini et al., 2020).

The present study observed that from the 6 articles selected for the equine species, 5 were studies performed by professionals trained in Traditional Chinese Medicine. These data may be related to the fact that acupuncture professionals participate in the horse rehabilitation process or also because they are familiar with the occurrence of TP, since studies have shown that about 70 to $75 \%$ of the points coincide with each other, that is, there is a strong 
correlation between acupuncture points and TP (Bowen et al., 2017; Fry et al., 2014; MacGregor \& Von Schweinitz, 2006; Pellegrini et al., 2020; Ridgway, 1999).

The limitation found by the present study was the scarcity of studies addressing the theme MPS and TP. Although studies on canine and equine species have shown good clinical applicability, prospective and randomized studies are lacking. In addition, the feline species was not addressed, due to the total scarcity of articles contemplating the particularities of the species.

\section{Conclusions}

In dogs, the occurrence of TP was related to other comorbidities, assuming a chronic character. For horses, the occurrence of MPS and TP is linked to poor performance.

\section{References}

Borg-Stein J, Iaccarino MA. Myofascial pain syndrome treatments. Phys Med Rehabil Clin N Am. 2014;25(2):357-74. http://dx.doi.org/10.1016/j.pmr.2014.01.012. PMid:24787338.

Bowen AG, Goff LM, McGowan CM. Investigation of myofascial trigger points in equine pectoral muscles and girth-aversion behavior. J Equine Vet Sci. 2017;48:154-160. e1. http://dx.doi.org/10.1016/j.jevs.2016.04.095.

Brockman T. A case study utilizing myofascial release, acupressure and trigger point therapy to treat bilateral "Stringhalt" in a 12 year old Akhal-Teke horse. J Bodyw Mov Ther. 2017;21(3):589-93. http://dx.doi.org/10.1016/j. jbmt.2016.08.019. PMid:28750969.

Downing R. The role of physical medicine and rehabilitation for patients in palliative and hospice care. Vet Clin Small Anim. 2011;41(3):591-608. http://dx.doi.org/10.1016/j. cvsm.2011.03.011. PMid:21601748.

Fernández-de-Las-Peñas C, Nijs J. Trigger point dry needling for the treatment of myofascial pain syndrome: current perspectives within a pain neuroscience paradigm. J Pain Res. 2019;12:1899-911. http://dx.doi.org/10.2147/ JPR.S154728. PMid:31354339.

Formenton MR, Pereira MAA, Fantoni DT. Small animal massage therapy: a brief review and relevant observations. Top Companion Anim Med. 2017;32(4):139-45. http:// dx.doi.org/10.1053/j.tcam.2017.10.001. PMid:29525233.
Understanding the diagnostic methods, either clinical or with the aid of instruments, as well as noninvasive and invasive treatments, is fundamental for professional training. Overall, the present study suggests further studies are needed in order to meet the growing demand of professionals with emphasis on rehabilitation, palliative care or sports medicine, and thus improve the quality of life of dogs and horses with MPS and TP.

\section{Conflict of Interest}

No conflict of interest.

\section{Ethics Statement}

The present study is a bibliographic review, so there is no protocol from the ethics committee.

Frank EM. Myofascial trigger point diagnostic criteria in the dog. J Musculoskeletal Pain. 1999;7(1-2):231-7. http:// dx.doi.org/10.1300/J094v07n01_22.

Fry LM, Neary SM, Sharrock J, Rychel JK. Acupuncture for analgesia in veterinary medicine. Top Companion Anim Med. 2014;29(2):35-42. http://dx.doi.org/10.1053/j. tcam.2014.03.001. PMid:25454374.

Gerwin RD. Diagnosis of myofascial pain syndrome. Phys Med Rehabil Clin N Am. 2014;25(2):341-55. http://dx.doi. org/10.1016/j.pmr.2014.01.011. PMid:24787337.

Gerwin RD, Dommerholt J, Shah JP. An expansion of Simons' integrated hypothesis of trigger point formation. Curr Pain Headache Rep. 2004;8(6):468-75.

Hong CZ, Simons DG. Pathophysiologic and electrophysiologic mechanisms of myofascial trigger points. Arch Phys Med Rehabil. 1998;79(7):863-72. http://dx.doi.org/10.1016/ S0003-9993(98)90371-9. PMid:9685106.

Janssens LAA. Trigger points in 48 dogs with myofascial pain syndromes. Vet Surg. 1991;20(4):274-8. http://dx.doi. org/10.1111/j.1532-950X.1991.tb01263.x. PMid:1949567.

Landis JR, Koch GG. The measurement of observer agreement for categorical data. Biometrics. 1977;33(1):159-74. http:// dx.doi.org/10.2307/2529310. PMid:843571.

MacGregor J, Von Schweinitz DG. Needle electromyographic activity of myofascial trigger points and control sites in 
equine cleidobrachialis muscle: an observational study. Acupunct Med. 2006;24(2):61-70. http://dx.doi.org/10.1136/ aim.24.2.61. PMid:16783281.

Pellegrini DZ, Müller TR, Fonteque JH, Souza LP, Souza AF, Joaquim JGF. Equine acupuncture methods and applications: a review. Equine Vet Educ. 2020;32(5):268-77. http://dx.doi. org/10.1111/eve.12928.

Ridgway K. Acupuncture as a treatment modality for back problems. Vet Clin North Am Equine Pract. 1999;15(1):21121. http://dx.doi.org/10.1016/S0749-0739(17)30173-6. PMid:10218251.

Rogers P. Acupuncture for equine paraspinal myofascial pain. Am J Tradit Chin Vet Med. 2012;7:69-75.

Simons DG, Dommerholt J. Myofascial trigger points and myofascial pain syndrome: a critical review of recent literature. J Manual Manip Ther. 2006;14(4):125E-71E. http://dx.doi.org/10.1179/jmt.2006.14.4.125E.
Simons DG. Understanding effective treatments of myofascial trigger points. J Bodyw Mov Ther. 2002;6(2):81-8. http:// dx.doi.org/10.1054/jbmt.2002.0271.

Teixeira MJ, Yeng LT, Hideko H, Kaziyama S, Ramos CA. Fisiopatologia da dor músculo-esquelética Physiopatology of the muscleskeletal pain. Rev Med. 2001;80:63-77.

Von Schweinitz DG. Thermographic diagnostics in equine back pain. Vet Clin North Am Equine Pract. 1999;15(1):16177, viii. http://dx.doi.org/10.1016/S0749-0739(17)30170-0. PMid:10218248.

Wall R. Introduction to myofascial trigger points in dogs. Top Companion Anim Med. 2014;29(2):43-8. http://dx.doi. org/10.1053/j.tcam.2013.11.001. PMid:25454375.

Yeng LT, Kaziyama HHS, Teixeira MJ. Síndrome dolorosa miofascial. Rev Med. 2001;80:94-110.

Financial Support: CNPQ. 